\title{
IMPLEMENTATION OF AN ACCESS SYSTEM TO THE AIR TRANSPORT MARKET IN ACCORDANCE WITH THE COMMON AVIATION AREA AGREEMENT
}

\begin{abstract}
Summary. While composing this article there has been a focus on analyzing Ukrainian legislation and comparing it to the European regulations, with identifying the possibilities and ways of improvement. Connection between financial condition of an airline and flight safety has been investigated as well. It has been proposed to improve the Article 7 "Proof of good repute" of Regulation (EC) No 1008/2008 by using comparative analysis between road and air legislation. It has also been recommended to add the article regarding good repute to the draft law of Ukraine about peculiarities of state regulation of aviation carriers' activity. Other proposed improvements include adding four new criteria to the access to air routes legislation of Ukraine.
\end{abstract}

Keywords: aviation area, good repute, operating licence, flight safety, risk mitigation, financial standings, access to air routes.

Ходурська М.Є., Шевченко Ю.В. Національний авіаційний університет

\section{ВПРОВАДЖЕННЯ СИСТЕМИ ДОСТУПУ ДО РИНКУ АВІАЦІЙНИХ ПЕРЕВЕЗЕНЬ ВІДПОВІДНО ДО УГОДИ ПРО СПІЛЬНИЙ АВІАЦІЙНИЙ ПРОСТІР}

\begin{abstract}
Анотація. Складаючи цю статтю, увага зосереджувалася на аналізі українського законодавства та порівнянні його з европейськими нормативними актами, з визначенням можливостей та шляхів вдосконалення. Досліджено зв'язок між фрінансовим станом авіакомпанії та безпекою польотів. Запропоновано поліпшити Статтю 7 «Про добру репутації» Регламенту (СС) № 1008/2008 шляхом використання порівняльного аналізу між дорожнім та повітряним законодавством. Також було рекомендовано додати до проекту закону України статтю про добру репутацію щодо особливостей державного регулювання діяльності авіаційних перевізників. Інші запропоновані вдосконалення включають додавання чотирьох нових критеріїв до законодавства України щодо доступу до повітряних маршрутів.
\end{abstract}

Ключові слова: авіаційний простір, добра репутація, ліцензія на експлуатацію, безпека польотів, зниження ризиків, платоспроможність, доступ до повітряних маршрутів.

Gormulation of the problem. Common Aviation Area makes the use of airspace more efficient and air traffic management safer; it cooperates with international organization Eurocontrol, which coordinates the planning and management of air traffic across Europe. The Agreement on the Common Aviation Area between Ukraine and the EU, provides for the incorporation into Ukrainian legislation $64 \mathrm{EU}$ regulations and directives in the field of aviation, which require much work and changes to be done.

Recent research and publications analysis. This research is based mostly on Ukrainian and EU legislation, such as Regulation No 1008/2008, Regulation No 1071/2009, Order No. 684, Law No. 1775-III, Order No. 134, Order No 686. However, there are some researches, whose scientific publications were taken into account and used while writing this article: Sizhe Xu, Reason J., Finger M., Holvad T., Peter M. Madsen, Deephouse D.L., Carter S.M.

Identification of previously unsettled parts of the general problem. Given the existence of legislative advances from the selected theme, it should be noted that some of the laws are debatable regarding their completeness, and a number of important aspects needs to be improved. Due with this choice of research topic and its target orientation are sufficiently relevant.

The purpose of the article. The main purpose is to define the ways of an access system implementation to the Ukrainian air transport market in accordance with Common Aviation Area Agreement and the ways of its improvement; to identify the good repute requirements for an airline, as well as represent the connection between financial condition of an airline and flight safety.

Main material presentation. European Common Aviation Area is a bilateral agreement between the EU and third countries to establish common standards of safety and liberalization of market relations in the field of aviation. Signing of the Common Aviation Area Agreement between Ukraine and the European Union is one of the priority tasks on the agenda in Ukraine. The implementation of the CAA Agreement is foreseen by the Association Agreement between Ukraine and the EU from 2014, the Action Plan of the Cabinet of Ministers of Ukraine for 2016 and the Strategic Plan for the Development of Air Transport until 2020.

Regulation (EC) No 1008/2008 on common rules for the operation of air services in the Community is one of the documents related to CAA Agreement, which states the rules for aviation activity. It consists of articles that describe general and financial conditions for granting an operating licence, its validity, suspension and revocation, proof of good repute, air operator certificate, insurance requirements, registration, leasing, access to routes and provisions for pricing. They also notably include the ability to demonstrate that it can meet actual and potential (financial) obligations for at least the 12 months (or for a period of 24 months from the start of operations), the obligation to communicate audited accounts to the licensing authority on 
a yearly basis and to comply with minimum insurance requirements in respect of passengers, baggage, cargo, mail and third parties; and the physical persons who will compose the management of the air carrier must be of good repute.

In Ukraine passenger and cargo transportation by air is subject to a special licence under the Law No. 1775-III dated 1 June 2000 on licensing of certain kinds of business activities. Such licence may be issued only to an operator - an air carrier with an active air operator certificate. The Air Code of Ukraine states that a licence may be issued to an operator that possesses at least one aircraft. The aircraft may be owned or dry-leased. The operator should provide air transportation within the terms and conditions stated in the AOC.

Certification of the operator is provided under the Rules of Operators' Certification approved by the Ukraine State Service for Aviation Safety, Order No. 684 dated 20 September 2005. These Rules apply regardless of the ownership forms and departmental membership of all civil aviation operators, who are registered on the territory of Ukraine as legal entities and carry out the operation of civil aircraft ships and are obligatory for them. The rules set the certification requirements to operators of civil aircraft, as well as certification procedures and external control of operators.

The Order No. 134 dated 10 March 2017 is about license terms economic activity of companies, which transport passengers, dangerous goods and dangerous goods waste by air. This Order does not have enough information on how licensing is done and moreover, which documents have to be provided by an operator that wants to get licensed.

EU regulations influence Ukrainian laws and make changes to the existing laws obligatory. A draft law of Ukraine about peculiarities of state regulation of aviation carriers' activity connected with transportation of passengers and/or cargo by is based on Regulation (EC) 1008/2008 articles about operating licence, financial conditions for granting operating licence, air operator certificate, validity of an operating licence, suspension and revocation of operating licence, and has all these rules are quite similar to the European legislation. There are also some differences, such as absence of proof of good repute article and insurance requirements. Moreover, the draft law does not state that there is an important connection between financial condition of an airline and aviation safety.

Financial standings requirements in accordance with Regulation 1008/2008. Recognizing the potential link between the financial health of the air carrier and safety, it is necessary to strengthen monitoring of air carriers financial status [2]. In order to ensure proper monitoring of compliance with the operating license requirements of all Community air carriers, licensing authorities should carry out regular assessments of the financial situation of air carriers. Therefore, the latter should provide the necessary information about their financial condition, especially during the first two years of its existence, since such information is especially important for the survival of the air carrier on the market. In order to avoid a breach of competition rules due to the different application of rules at the national level, it is neces- sary to strengthen the financial control of Member States by all Community air carriers [2].

For checking financial conditions for granting operating licence the competent licensing authority assesses whether the enterprise applying for the first time can at any time meet its potential obligations during the 24-month period from the commencement of operation and can also cover fixed and operational costs during the first three months without taking into account any profit from its activity. For this assessment each applicant must provide a business plan for at least first three years of the business. The business plan must contain a detailed description of the applicant's financial connection with any other commercial activity in which the applicant is involved directly or through the relevant enterprises.

It has been proved that there is a link between airline safety and the financial performance of the country in which an airline is based/registered/regulated. There is a stronger link to airline safety from being based in a country with strong law enforcement, higher GDP per capita and better economic growth compared to just an airline's profitability. From an analysis of a data set spread, (Table 1), Xu showed with $90 \%$ confidence that airlines based in countries "with laxer legal regulations, worse law enforcement, and poorer economic performance tend to have poorer safety performance" [7] and "significant results are confirmed for the relationship between accident frequency and GDP, the efficiency of the judicial system, the rule of law, and corruption" [7].

Finding a balance between the level of production and protection is very important in order to be a safe airline on an acceptable level. The safety space illustrated in Fig. 1. [8] shows that if the safety management is too low, an accident is almost inevitable and otherwise and in cases when financial conditions are overestimated and an airlines uses too match resources for safety measures - bankruptcy is unavoidable.

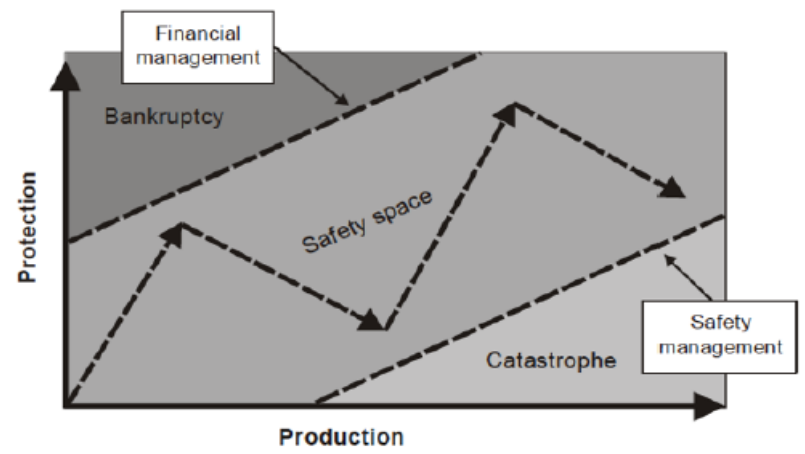

Fig. 1. The safety space

Source: [8]

One of the most important aspects of safety and well-functioning of an organization, in our case an airline or an aviation enterprise, is being of a good repute. Good repute has to be proved by the owner, top rank managers and the organization as a whole. Regulation (EC) No 1008/2008 of the European Parliament and of the Council of 24 September 2008 on common rules for the operation of air services in the Community has proof of good repute requirement in Article 7. 
Table 1

Link between airline safety and the financial performance of the country in which an airline is based

\begin{tabular}{|c|c|c|c|c|c|}
\hline \multirow[b]{2}{*}{ Country } & \multirow[b]{2}{*}{$\begin{array}{c}\text { Number } \\
\text { of accidents } \\
(1990-2009)\end{array}$} & \multicolumn{4}{|c|}{ Average (1990 - 2009) } \\
\hline & & $\begin{array}{c}\text { Number of } \\
\text { passengers } \\
\text { carried (million) }\end{array}$ & $\begin{array}{l}\text { GDP (\$ billion) } \\
\text { descending }\end{array}$ & $\begin{array}{c}\text { GDP } \\
\text { (growth \%) }\end{array}$ & $\begin{array}{l}\text { Population } \\
\text { (million) }\end{array}$ \\
\hline US & 70 & 600.5 & 10113.2 & 2.5 & 279.5 \\
\hline Japan & 5 & 95.6 & 4373.5 & 1 & 126.4 \\
\hline Germany & 2 & 60 & 2400.4 & 1.5 & 81.8 \\
\hline France & 11 & 46.5 & 1720.5 & 1.6 & 61.2 \\
\hline UK & 8 & 71.7 & 1666.2 & 2.3 & 59.1 \\
\hline Italy & 10 & 28.8 & 1431.7 & 1 & 57.6 \\
\hline Canada & 4 & 31.9 & 835.9 & 2.3 & 30.7 \\
\hline Spain & 13 & 36.9 & 819.5 & 2.6 & 41.2 \\
\hline Brazil & 16 & 31.6 & 784.3 & 2.5 & 172.7 \\
\hline India & 16 & 22.5 & 602.2 & 6.3 & 1032.4 \\
\hline South Korea & 6 & 30 & 583 & 5.3 & 46.4 \\
\hline Netherlands & 2 & 19.8 & 489.4 & 2.4 & 15.8 \\
\hline Turkey & 6 & 12.3 & 311.4 & 3.9 & 62.7 \\
\hline Austria & 2 & 6 & 248.3 & 2.2 & 8 \\
\hline Thailand & 2 & 15.4 & 156.8 & 4.7 & 61.9 \\
\hline Portugal & 1 & 6.9 & 144.8 & 1.9 & 10.3 \\
\hline Colombia & 7 & 8.9 & 112.6 & 3.5 & 39.6 \\
\hline Malaysia & 5 & 16.4 & 109.5 & 6 & 23.1 \\
\hline Singapore & 2 & 14.3 & 100.2 & 6.2 & 3.9 \\
\hline Pakistan & 7 & 5.4 & 84.3 & 4.2 & 141.1 \\
\hline
\end{tabular}

Source: developed by the author according to the data [7]

Reputation, can arise from stakeholders perception and evaluation of the organization and can be seen as an asset of high importance due to the effect it has on the organization's ability to acquire resources. A good repute can also result in the customer giving the company the "benefit of the doubt" when experiencing uncertainty in a crisis situation. This depends on how strong the relationship is between the organization and the stakeholders and how much the stakeholders have invested in the relationship. If stakeholder relationships are not strong before the crisis, those stakeholders that are harmed by the crisis or support those groups harmed by the crisis will withdraw their support and possibly worsen or prolong the crisis situation [9]. The requisites are not too restrictive: they include the exigency that the company hold an Air Operator Certificate (defined in line with ICAO recommendations), comply with insurance and ownership requirements, and provide financial guarantees. In addition, the management will be requested to provide proof that the undertaking is of good repute. With respect to pricing rules, they are minimal. Regulation 1008/2008 states that fares are freely set, but they should be informative and non-discriminatory [10].

The Article 7 Proof of good repute of Regulations 1008/2008 states that for the issuance of an operating license, it must be shown that persons, who will continuously and effectively manage the business have a good reputation and are not de- clared bankrupt, the competent licensing authority must accept as sufficient evidence, for citizens of the Member States, documents issued by the competent authorities of the home Member State or the Member State where the person has his permanent residence, which proves the fulfillment of these requirements. The competent licensing authority requires the documents to be submitted not later than 3 months after issue date.

Comparative analysis of good repute legislation between road and air transport and recommendations for improvements to the latter. Road sector is one of the most liberalized sectors in Europe. As for bilateral international transport and crosstrade, access is based on a community licence which is issued by the relevant national authority to the hauler and valid across Europe on the basis of fulfilling qualitative criteria (such as being of good repute in terms of no conviction for any infringement of national rules in certain fields, for example commercial law, road traffic, trafficking in human beings or drugs, as well being able to meet financial obligations) [10].

Regulation No 1071/2009 dated 21 October 2009 establishes common rules concerning the conditions to be complied with to become a road transport operator. Article 6 of Regulation 1071/2009 lists the conditions relating to the requirement of good repute. It has been decided to compare the articles regarding good repute of both road and air transport legislation, as the rules in road transportation regulations were found more complete and precise. 
After analyzing the various details in road transportation Regulation we advise to add some cases to the Regulation 1008/2008 to improve the proof of good repute conditions, specifically about:

1. working time and rest period for cabin crew and pilots;

2. exceeding maximum loading weight or not properly loading the aircraft;

3. delays and regularity of aircraft movements;

4. infringements of national rules in the fields of commercial law;

5. infringements in the field of pay and employment conditions.

Improvements to the legislation allowing access to routes. Order No 686 dated 13 November 2014 on Aviation Rules of Ukraine "Procedure for granting and cancellation of rights to operate air routes" has a special way of choosing which airline will operate on a certain route. If State Aviation Administration of Ukraine has received applications from two or more air carriers for the same route, the corresponding right is granted to the air carrier, which received more points according to the criteria.

The winner of each criterion receives the maximum number of points. The number of points of the remaining participants is calculated by the formula:

Pparticipant $=M \times$ Iparticipant $\div$ Iwinner

where $\mathrm{M}$ - the maximum number of points;

$\mathrm{P}$ - number of points of the participant (except for the winner according to the relevant criteria);

$\mathrm{I}_{\text {participant }}$ - participant's indicator according to the relevant criteria;

$I_{\text {winner }}$ - indicator of the winner according to the relevant criteria.
The result is rounded to one hundredth. After that, the results are added. The winner is the air carrier that received the highest score on all criteria. Criteria, which should be taken into account by the Commission, is represented in the Table 2.

After analyzing the existing criteria it has been decided that there are few improvements that can be made. They would increase the level of safety, service and good repute in Ukrainian airlines. The proposed criteria are represented in Table 3.

The first recommended criterion is proof of fitand-proper-person or a proof of good repute. Fit-andproper-person test or director's test is a test aiming to prevent corrupt or untrustworthy businessmen from serving on the board of certain organizations. For evaluation of fit and proper person only two variants of points can be used, and they are 10 or 0 .

The second recommendation is the requirement that the applicant (airline) provide evidence of a fatigue management system. ICAO has a performance-based approach that requires the service provider to implement a FRMS that is approved by the State. The number of points given should be regulated by the independent party, which evaluates fatigue management quality.

Third recommendation for improvement of Order No 686 is establishing a requirement for an airline to prove through a business plan that the applicant will operate a viable business with sufficient staffing levels to meet both aviation minimum flight crew regulatory requirements and hold enough staff in excess of that minimum in order to meet Ukrainian workplace leave entitlements (of 24 days) under Law of Ukraine about vacations. Crew members complain they often don't get enough rest, working long

Table 2

Criteria for granting rights to operate on an air route

\begin{tabular}{|l|c|}
\hline \multicolumn{1}{|c|}{ Criteria } & $\begin{array}{c}\text { Number } \\
\text { of points } \\
\text { (maximum) }\end{array}$ \\
\hline $\begin{array}{l}\text { Actual use by the air carrier of the previously granted rights to operate the air routes (the ratio of } \\
\text { frequencies of performed flights to the total number of frequencies on which the air carrier has been } \\
\text { granted the rights to operate). }\end{array}$ & 10 \\
\hline $\begin{array}{l}\text { The amount of money paid to the State Budget of Ukraine for the last 12 consecutive months } \\
\text { preceding the month in which the application was filed, per one aircraft. }\end{array}$ & 10 \\
\hline $\begin{array}{l}\text { The number of aviation incidents and accidents per one million flights that the air carrier is required to } \\
\text { report to the State Aviation Service during the last 12 consecutive months preceding the filing date (the } \\
\text { lower the coefficient, the higher the score). If the air carrier does not have a flight safety management } \\
\text { system and the procedure for conducting internal investigations and / or analysis of events and / or } \\
\text { there is no flight statistics, according to this criterion, such air carrier receives 0 points. }\end{array}$ & 10 \\
\hline $\begin{array}{l}\text { Regularity of flights performed during the last 6 months preceding the day of filing an application } \\
\text { (percentage of flights performed without delays from the total number of flights for the specified period). }\end{array}$ & 10 \\
\hline
\end{tabular}

Source: developed by the author according to the data [5]

Table 3

Proposed criteria for improvements of Order No 686 dated 13 November 2014

\begin{tabular}{|l|c|}
\hline \multicolumn{1}{|c|}{ New criterion } & $\begin{array}{c}\text { Number } \\
\text { of points } \\
\text { (maximum) }\end{array}$ \\
\hline Fit-and-proper-person test/ Proof of good repute & 10 \\
\hline Evidence of a fatigue management system & 10 \\
\hline $\begin{array}{l}\text { Sufficient staffing levels in order to meet workplace leave entitlements (of 24 days) under Law of } \\
\text { Ukraine about vacations }\end{array}$ & 10 \\
\hline Aviation Safety Reporting System & 10 \\
\hline Proof of Airworthiness & 10 \\
\hline
\end{tabular}

Source: developed by the author 
hours and frequently unable to take allotted holiday time, except in cash. Georgian said in a memo last November it had only been able to award 25 per cent of pilots' 2017 vacation. [11].

The fourth advice would be to check Aviation Safety Reporting System as voluntary reporting is a world-wide used system and very well known for improving safety and preventing new aviation incidents or accident.

The last but not the least recommendation is proving airworthiness of an aircraft. The level of airworthiness should be measured in percentage and then transformed into 0 to 10 points, where $100 \%$ is a maximum of 10 points.

Conclusions and suggestions. On the basis of everything mentioned in the report a conclusion that Ukrainian legislation has to be improved and brought to the level of EU regulations can be made. A draft law of Ukraine about peculiarities of state regulation of aviation carriers' activity connected with transportation of passengers and/or cargo by air is based on European common rules for the operation of air services is a good start but is still a project.

As a consequence of market opening, travel opportunities for EU and Ukrainian passengers would improve and there would be economic benefits for EU and Ukrainian airlines and airports. It is important to ensure that the opening and the integration of the markets is undertaken in a balanced manner taking into account other important policy objectives and mitigating potential adverse impacts. In this context, it will be essential to ensure that the process of market opening is accompanied by a parallel process of regulatory co-operation and gradual convergence. This is particularly important in crucial areas such as safety, security, environmental protection and application of competition law.

\section{References:}

1. Draft Common Aviation Area Agreement between the European Union and its member states and Ukraine.

2. Regulation (EC) No 1008/2008 of the European Parliament and of the Council of 24 September 2008 on common rules for the operation of air services in the Community.

3. Council Regulation (EEC) No 3922/91 of 16 December 1991 on the harmonization of technical requirements and administrative procedures in the field of civil aviation.

4. Order No 134 dated 10 March 2017 "License terms regarding transportation of passengers, dangerous goods and dangerous goods waste on air transport".

5. Order No 686 dated 13 November 2014 on Aviation Rules of Ukraine "Procedure for granting and cancellation of rights to operate air lines".

6. Regulation (EC) No 1071/2009 of the European Parliament and of the Council of 21 October 2009 establishing common rules concerning the conditions to be complied with to pursue the occupation of road transport operator and repealing Council Directive 96/26/EC.

7. Sizhe Xu. The relationship between financial performance and safety in the aviation industry: a worldwide perspective. - 2015. - 56 p. URL: https://spectrum.library.concordia.ca/979839/1/Xu_MSc_S2015.pdf.

8. Reason J. Managing the Risks of Organizational Accidents 1st Edition. - 1997. - 252 p.

9. Deephouse, D.L. and Carter, S.M. "An Examination of Differences Between Organizational Legitimacy and Organizational Reputation”, Journal of Management Studies. - 2005. - 329-360 p.

10. Finger M., Holvad T. Regulating Transport in Europe. - 2013. - 264 p.

11. "Cabin pressure: Are airline contractors cutting corners on safety to earn business?" URL: http://business.financialpost.com/feature/cabin-pressure-are-airline-contractors-cutting-corners-on-safetyto-earn-business. 